\title{
DETERMINANT FACTORS OF DEPRESSION IN BETA MAJOR THALASSEMIA CHILDREN
}

\author{
Hapsari Widya Ningtiar ${ }^{1}$, Ahmad Suryawan ${ }^{1 *}$, Irwanto $^{1}$, IDG Ugrasena ${ }^{1}$ \\ ${ }^{1}$ Department of Child Health, Faculty of Medicine, Universitas Airlangga, Dr Soetomo Academic Hospital \\ Surabaya, Indonesia
}

\begin{abstract}
Thalassemia is a chronic disease with long-term treatment that increases the potential for impact on physical, cognitive, and psychological conditions. About $80 \%$ of patients with major thalassemia have at least one psychiatric disorder. Depression is one of the most frequently reported, especially in prepubertal and puberty periods. The study aimed to evaluate determinant factors of depression in beta mayor thalassemia children. This study was a cross-sectional study on patients aged 9 to 17 years at hematology outpatient clinic in Dr Soetomo Academic Hospital from September to Desember 2018. The level of depression determinded by Children Depression Inventory (CDI) questionnaire. The data were collected and analyzed using the IBM SPSS Statistics version 21. It was statistically significant with $p<0.05$. Forty five participants were included in this study, 15 participants with mild depression and 30 participants without depression. Gender $(P=0.462)$, age of diagnosis $(P=0.385)$, frequency of tranfussion $(P=0.065)$, family history of depression $(P=0.350)$, physical change $(P=0.711)$, duration of illness $(P=0.674)$ had no significant value as a determinant factor while complication $(P=0.049)$ and serum cortisol level $(P=$ $0.037)$ had significant value as determinant factors of depression in Beta Major Thalassemia children. In conclusion, mild depression was more common in thalassemia patients who experienced complications and had high serum cortisol levels.
\end{abstract}

Keywords: beta major thalassemia; level of depression; children depression inventory (cdi)

\section{ABSTRAK}

Thalassemia adalah penyakit kronis dengan pengobatan jangka panjang yang meningkatkan potensi dampak pada kondisi fisik, kognitif, dan psikologis. Sekitar $80 \%$ pasien dengan thalassemia mayor memiliki setidaknya satu gangguan kejiwaan, depresi adalah salah satu yang paling sering dilaporkan, terutama pada periode prapubertas dan masa pubertas. Tujuan dari penelitian ini adalah untuk mengevaluasi faktor-faktor penentu depresi pada anak-anak thalassemia beta mayor. Penelitian ini adalah studi cross-sectional pada pasien berusia 9 hingga 17 tahun di klinik rawat jalan hematologi di Rumah Sakit Umum Dr Soetomo dari September hingga Desember 2018. Tingkat depresi ditentukan oleh kuesioner Children Depression Inventory (CDI). Data dikumpulkan dan dianalisis menggunakan IBM SPSS Statistics versi 21. Nilai signifikan secara statistik adalah $p$ $<0,05$. Empat puluh lima peserta dilibatkan dalam penelitian ini, 15 peserta dengan depresi ringan dan 30 peserta tanpa depresi. Jenis kelamin $(P=0,462)$, usia diagnosis $(P=0,385)$, frekuensi tranfusi $(P=0,065)$, riwayat keluarga depresi $(P=$ $0,350)$, perubahan fisik $(P=0,711)$, lama sakit $(P=0,674))$ memiliki nilai yang tidak signifikan, sedangkan komplikasi $(P=$ $0,049)$ dan kadar kortisol serum $(P=0,037)$ signifikan sebagai faktor penentu depresi pada anak Beta Major Thalassemia. Sebagai simpulan depresi ringan lebih sering terjadi pada pasien talasemia yang mengalami komplikasi dan kadar serum kortisol yang tinggi.

Kata kunci: beta major thalassemia; tingkat depresi; inventarisasi depresi anak (cdi)

Correspondence: Ahmad Suryawan, Department of Child Health, Faculty of Medicine, Universitas Airlangga, Dr. Soetomo Academic Hospital Surabaya, Indonesia. Jl. Mayjen Prof. Dr. Moestopo No 6-8, Surabaya, East Java 60286. E-mail: ahmad.suryawan@fk.unair.ac.id

pISSN:2355-8393 • eISSN: 2599-056x • doi: 10.20473/fmi.v57i1.13664

- Fol Med Indones. 2020;57:46-52 • Received 14 Jun 2019 • Accepted 20 Dec 2019

- Open access under CC-BY-NC-SA license • Available at https://e-journal.unair.ac.id/FMI/

\section{INTRODUCTION}

Thalassemia is an autosomal recessive genetic disease group characterized by failure to produce a synthesis of normal ß-globin chains (Olivieri \& Weatherall 2006, Hastings et al 2012, Sarker \& Shahriar 2017). Thalassemia has the characteristics of severe anemia, hepatosplenomegaly, bone deformity and endocrine 
abnormalities include growth and development disorders, late puberty which can be accompanied by damage to the hypothalamic-pituitary axis (Nasiri et al 2014).

Patients with thalassemia need a long period treatment that has potential to have an physical, cognitive, and psychological impact (Permono \& Ugrasena 2006, Mednick et al 2010). Psychological disorders occured in 1: 4 of 38 patients with thalassemia major aged 6-18 years in Turkey, and about $24 \%$ experienced depression (Aydinok et al 2005). Another study showed thalassemia patients aged 7-18 years as many as $49 \%$ experience depression and $62.7 \%$ with irritable and anxious. More than $43 \%$ had a desire to commit suicide and $27.3 \%$ died of suicide (Ghanizadeh et al 2006).

Chronicity of the disease and long-term treatment can be stressors that cause depression and susceptible to other stressors. This condition triggers an imbalance from the factors that influence the emergence of depression disorders. Depression will be responded by the hypothalamic-pituitary-adrenal (HPA) axis, causing an increase in basal cortisol levels, which will cause continuing symptoms of depression, damage the brain, reduce endurance and worsen the course of the disease. Under other condition the state of Iron toxicity can affect the HPA axis at different levels indicated by the presence of lower ACTH levels (Baldini et al 2017).

The increased risk of psychological and behavioral disorders in patients with thalassemia indicates the importance of long-term psychosocial support and prevention of the emergence of mental disorders in order to improve the quality of life. It was concluded that psychological evaluation needs to be routinely done (Bush et al 1998, Messina et al 2008). The impact of depression at young age have associated with negative long-term outcomes of mental and functional health, including disorders that occurred during school, and substance abuse interpersonal relationship and suicide attemps (Gladstone \& Beardslee 2009).

Many studies published about psychiatric problems in patients with Beta Major Thalassemia, but there are limited number of studies investigating the determinant factor of depression in Beta Major Thalassemia in Dr Soetomo Academic Hospital. In the present study, this study aimed to identify the prevalence of depression in children with thalassemia major and its determinant factors. Identifying factors could help with prevention and increased the quality of life.

\section{MATERIALS AND METHODS}

A cross-sectional study was conducted in the Hematologic outpatient clinic of Dr. Soetomo Academic Hospital, Surabaya, Indonesia in September to November 2018. The subjects were children aged 7 to 18 years old who were diagnosed as Beta Mayor Thalassemia by haematology and oncology consultant. In all subjects, the degree of depression was evaluated using Children Depression Inventory (CDI) questionnaire which divided into mild (13-17), moderate (18-23) and severe depression (24-54) according to the CDI score. Serum cortisol test was using the Immunochemiluminescence method, collected from venous blood in the cubiti region. Blood sampling for serum cortisol was carried out at 08.00-10.00 am. The subjects were excluded if they had another chronic disease apart from thalassemia and its complications, drugs that affected blood cortisol levels, acure illness or conditions that could increase serum cortisol levels.

This study determined gender, age of diagnosis, frequency of tranfusion, family history of depression, physical change, duration of illness, complication and serum cortisol level as factors that influenced depression in Thalassemia children. Statistical analysis was performed using SPSS 21. Significant was indicated by $\mathrm{p}$-value $(\mathrm{P}<0.05)$. This study was approved by the Ethics Committee of Dr. Soetomo Academic Hospital.

\section{RESULTS}

Of 56 beta major thalassemia patients in the Hematology outpatient clinic 45 met the inclusion criteria during the study period. We excluded 11 patients, 4 patients with alpha thalassemia and 7 patient with the age below 7 years old (Figure 1). The characteristics of the subject were listed in Table 1. 


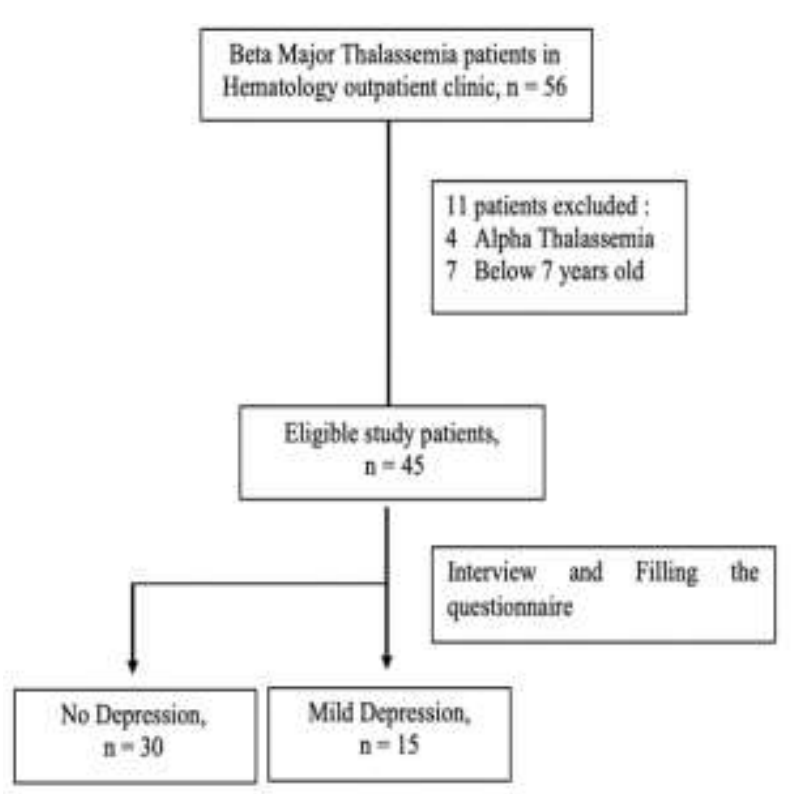

Figure 1. Subject recruitment

Table 1. Subject Characteristics

\begin{tabular}{|c|c|c|}
\hline Characteristics & $(\mathrm{n})$ & $(\%)$ \\
\hline \multicolumn{3}{|l|}{ Gender } \\
\hline Male & 22 & 49 \\
\hline Female & 23 & 51 \\
\hline Age, median (min-maks) & \multicolumn{2}{|c|}{$\begin{array}{c}11.7(7-17) \text { years } \\
\text { old }\end{array}$} \\
\hline Age (Year) & & \\
\hline $7-10$ & 24 & 53 \\
\hline $11-14$ & 14 & 31 \\
\hline $15-18$ & 7 & 16 \\
\hline
\end{tabular}

\begin{tabular}{|c|c|c|}
\hline \multicolumn{3}{|l|}{ Nutritional Status } \\
\hline Normal & 35 & 78 \\
\hline Moderate Malnutrition & 10 & 22 \\
\hline \multicolumn{3}{|l|}{$\mathrm{Hb}$ pretransfusion rate } \\
\hline$<6 \mathrm{~g} / \mathrm{dL}$ & 1 & 2.2 \\
\hline $6-8 \mathrm{~g} / \mathrm{dL}$ & 41 & 91.1 \\
\hline$>8 \mathrm{~g} / \mathrm{dL}$ & 3 & 6.7 \\
\hline \multicolumn{3}{|l|}{ Ferritin level } \\
\hline$<1000$ & 3 & 6.7 \\
\hline$\geq 1000$ & 42 & 93.3 \\
\hline \multicolumn{3}{|l|}{ Chelating Agent Type } \\
\hline DFP & 29 & 64 \\
\hline DFX & 16 & 36 \\
\hline \multicolumn{3}{|c|}{ Degree of depression (CDI score) } \\
\hline \multicolumn{3}{|l|}{ No depression } \\
\hline Mild & 30 & 66.7 \\
\hline Moderate & 15 & 33.3 \\
\hline \multirow[t]{2}{*}{ Severe } & 0 & 0 \\
\hline & 0 & 0 \\
\hline \multicolumn{3}{|c|}{$\begin{array}{l}\text { Out of } 45 \text { patients, } 30 \text { patient categorized as no } \\
\text { depression and } 15 \text { patients with mild depression, } \\
\text { determinant factors of the degree of depression all } \\
\text { shown in Table } 2 \text {. Determinant factors that influence } \\
\text { the level of depression significantly were complication } \\
\text { and serum cortisol levels. The scatterplot describe the } \\
\text { correlations between the serum cortisol level with the } \\
\text { degree of depression in Beta Major Thalassemia } \\
\text { (Figure 2) }\end{array}$} \\
\hline
\end{tabular}

Table 2. Determinant factors of mild depression in Beta Major Thalassemia

\begin{tabular}{|c|c|c|c|}
\hline Determinant factors & $\begin{array}{c}\text { No depression } \\
\mathrm{N}(\%) \\
\end{array}$ & $\begin{array}{c}\text { Mild Depression } \\
\mathrm{N}(\%)\end{array}$ & $\mathrm{P}$ \\
\hline \multicolumn{4}{|l|}{ Gender } \\
\hline Male & $15(46.9)$ & $7(58.8)$ & 0.462 \\
\hline Female & $17(53.1)$ & $6(46.2)$ & \\
\hline \multicolumn{4}{|l|}{ Age at diagnosis (year) } \\
\hline$<1$ & $6(18.7)$ & $4(30.8)$ & 0.385 \\
\hline $1-5$ & $17(53.1)$ & $4(30.8)$ & \\
\hline$>5$ & $9(28.2)$ & $5(38.4)$ & \\
\hline \multicolumn{4}{|l|}{ Frequency of tranfusion } \\
\hline$<12$ x/year & $2(6.3)$ & $1(7.7)$ & 0.065 \\
\hline$>12 x /$ year & $30(93.7)$ & $12(92.3)$ & \\
\hline \multicolumn{4}{|l|}{ History of Splenectomy } \\
\hline Yes & $0(0)$ & $1(7.7)$ & 0.289 \\
\hline No & $32(100)$ & $12(92.3)$ & \\
\hline \multicolumn{4}{|l|}{ Family History of Depression } \\
\hline Yes & $3(9)$ & $0(0)$ & 0.350 \\
\hline No & $29(91)$ & $13(100)$ & \\
\hline \multicolumn{4}{|l|}{ Family History of Thalassemia } \\
\hline Yes & $8(25)$ & $0(0)$ & 0.078 \\
\hline No & $2(6.2)$ & $0(0)$ & \\
\hline Not Test & $22(68.8)$ & $13(100)$ & \\
\hline
\end{tabular}




\begin{tabular}{lccc}
\hline Physical Change & $15(33.3)$ & $8(61.5)$ & 0.711 \\
Facies Cooley & $25(55.6)$ & $10(76.9)$ & \\
Hyperpigmentation & $21(46.7)$ & $12(92.3)$ & \\
Abdominal enlargement & & & \\
Duration of Illness (year) & $0(0)$ & 0 & 0.674 \\
$<1$ & $3(9.4)$ & $1(7.7)$ & \\
$1-5$ & $29(90.6)$ & $12(92.3)$ & \\
$>5$ & & & \\
Complications & $24(75)$ & $13(100)$ & $0.049^{*}$ \\
Yes & $8(25)$ & $0(0)$ & \\
No & & & \\
Cortisol serum level & $23(71.9)$ & $12(92.3)$ & $0.037^{*}$ \\
Normal & $9(28.1)$ & $0(0)$ & \\
Low & $0(0)$ & $1(7.7)$ & \\
High & Median $8.80(\mathrm{SD} \pm 4.07)$ & \\
Cortisol serum rate & &
\end{tabular}

*Chi-Square test; Fisher exact test, $\mathrm{p} \leq 0.05$

Figure 2. Scatter plot of cortisol serum level and level of depression (CDI Score)

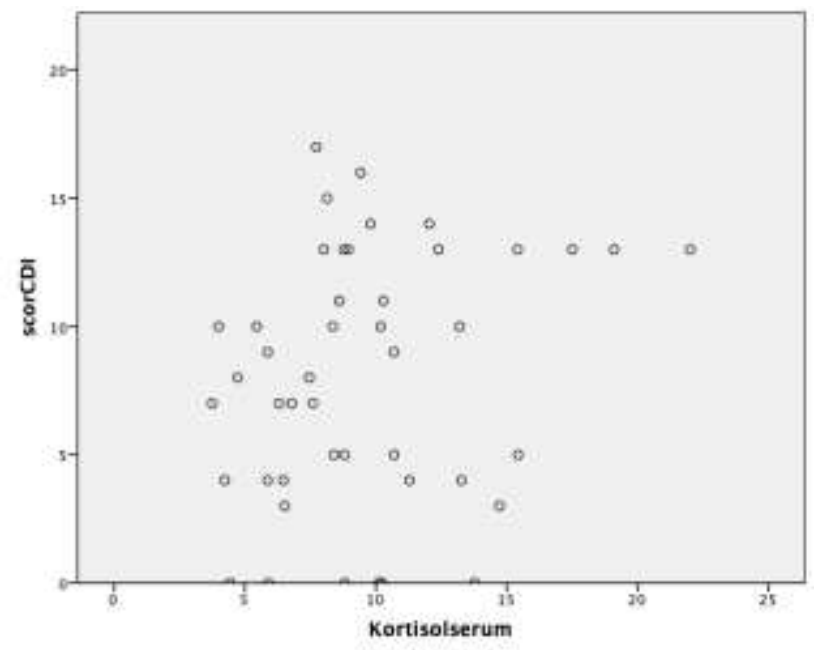

\section{DISCUSSION}

Previous studies had received reports of depressive disorders in patients with Beta Major Thalassemia. Savari (2007) reported depression occurred in $14 \%$ of patients with Beta Major Thalassemia and Intermedia, while Aydinok (2005) reported that $24 \%$ of patients with Beta Major Thalassemia experienced psychiatric disorders, such as depression (Aydinok et al 2005). Fifty percent of children aged 13-18 years with thalassemia major who seek treatment at the Thalassemia Center Department of Child Health FKUI Cipto Mangunkusumo Hospital had a poor quality of life, as many as $77.3 \%$ of subjects had poor psychosocial functions (Aji et al 2009). Thalassemia is a chronic disease that presents serious clinical and psychological challenges. The side effects of thalassemia on physical appearance can cause changes in body shape, growth disorders, and delayed puberty. Changes in physical appearance also contribute to a bad self-image. Serious complications that can occur such as heart failure, arrhythmia, liver disorders, endocrine complications and infections (Behdani et al 2015).

Clinical characteristic showed that there were no significant different in gender, ages, nutritional status, social economy status, and education. There were 23 males (49\%) and 22 females (51\%). Seven male participants and 8 female participants were mild depression. gender, age of diagnosis, frequency of tranfusion, family history of depression, physical change, duration of illness, complication and serum cortisol level suspected to had significant value as determinant factors of depression in Beta Major Thalassemia children.

There were 22 males (49\%) and 23 females (51\%) children with beta major thalassemia. A total of 7 male 
and 8 female experienced mild depression. In this study, there were no significant differences between male and female patients with Beta Major Thalassemia on the emergence of depression. The proportion of sex in this study was balanced between men and women. In accordance with Mariani et al study in 2011 showed that there were no significant differences between the quality of life of boys and girls (Mariani et al 2011). In the study, that the major beta thalassemia was inherited autosomal recessively regardless of gender.

The age at diagnosis of beta major thalassemia could affect the length of treatment and complications arising from the disease. Diagnosis and treatment of thalassemia was one of the severe stressors that could cause various emotional challenges and psychological disorders (Velasco-Rodriguez et al 2014). This study had several age groups when diagnosed with beta major thalassemia, including less than 1 year as many as 4 out of 10 children (40\%) experiencing depression, age 1-5 years as many as 5 out of 21 children (24\%) experiencing depression and more than 5 In the year 6 out of 14 children (43\%) experienced depression. Yet, the age difference was not significantly different. The amount of parental, family and environmental support greatly influenced the patient's resistance to stressors that appeared as thalassemia patients.

From this study, there were $93.3 \%$ of patients ran blood transfusions as much as 12 times per year. Blood transfusion is the main treatment in major beta thalassemia patients. Chronic transfusion prevents most complications, but complications related to blood transfusion were the major sources of thalassemia morbidity. Beta thalassemia major had a large negative impact on children. Children with thalassemia faced stressful effects throughout their lives, including frequent blood sampling for laboratory tests, frequency of transfusions and frequent subcutaneous injections and oral therapy of iron chelator drugs, all of which mad patients vulnerable to psychiatric loads such as depression and anxiety (Pattanashetti et al 2017). Venty's study showed no correlation between the frequency of blood transfusions, pre-transfusion hemoglobin levels and depression (Venty et al 2018). However, it was different from other studies which showed a correlation between the frequency of blood transfusion and depression. Blood transfusion more often caused an increase in school absenteeism and affects patients interacting socially with their peers. Therefore, they felt isolated and vulnerable to depression (Venty et al 2018).

A history of splenectomy in 1 child with mild depression, 44 children without splenectomy as many as 14 children experienced mild depression. Splenectomy was performed on thalassemia patients who had recurrent blood transfusion, symptomatic splenomegaly and failure to thrive (Mazzone et al 2009). The action of splenectomy was expected to reduce the frequency of transfusion and iron chelation therapy. A family history of depression could have an influence on the level of biology-genetic or lead to cognitive or social-behavioral vulnerability. The history of psychiatric disorders in families had received attention, especially in children who experience chronic pain as a risk factor for depression (Khurana et al 2006). In this study, there were 3 children (7\%) who had families with a history of depression and 42 children (93\%) had no family with a history of depression, but statistically the two groups did not have significant differences. The number of patients who did not had a family history of depression in this study was far more than those who had a family depression. None of the children with a family history of depression did not suffer from depression, so that there was no relationship between family history of depression and the emergence of depression in patients with beta major thalassemia in this study.

Thalassemia is not contagious but it is inherited, transmitted from parents to boys in an autosomal recessive pattern (Sun \& Wang 2014). In this study group, there were 12 children $(27 \%)$ who had a history of thalassemia in the family, 2 children (4\%) had no history of thalassemia in the family and 31 children (69\%) had never been examined. There were no significant differences between the three groups with values. It was difficult to ascertain the cause of not significant history of thalassemia in the family against the emergence of depression, because the number of parents who were not examined was quite a lot.

Disease and treatment that people undergoing thalassemia can cause several problems. When compared with healthy children, children with thalassemia have more physical symptoms and somatic complaints. Physical changes they experience due to chronic anemia and treatment that causes iron deposits in the organs of the body (Bulan 2009). Physical changes that occur include clinical pallor, enlarged spleen, facies cooley, hyperpigmentation, distended stomach. Research conducted by Bulan found that spleen size was a significant factor in quality of life. Enlargement of the spleen causes the abdomen to bulge, causing pressure on the abdominal cavity resulting in decreased mobility and appetite for children. Physical changes also occurred in the sample of this study group, including facies cooley of 17 children with 7 children $(41.2 \%)$ experiencing mild depression, hyperpigmentation of 35 children with 11 children (31.4\%) experiencing mild depression and distended abdomen 36 children $(38.9 \%)$ with 14 children 
experiencing mild depression. The overall characteristics have no significant difference in depression. Physical changes in patients do not become stressors that affect susceptibility to depression, judging from the number who experience mild depression in groups that do not have physical changes, it is quite comparable. The support of parents, family, environment and self esteem greatly affects the level of vulnerability to depression.

The duration of illness and the degree of depression did not have a significant relationship $(\mathrm{P}=0.674)$. The number of participants who suffered from mild depression was $73.3 \%$ in the duration of illness more than 5 years. No significant result could be influenced by the presence of environmental factors, like family, social, personal factors that strengthen resistance to depression. The same results were obtained in the study by Venty, that the duration of illness with an average value of 8 years (SD 4) did not find a significant relationship with depression. According to the study, the difference in his study was also influenced by genetic factors, social demographic factors, psychological factors, social factors and different types of questionnaires used in each study (Venty et al 2018). In contrast to previous studies by Khurana which explained that the longer the patient suffers from an illness, the higher degree of depression, because the longer patient got uncomfortable treatment from symptoms of persistent disease and actions during treatment (taking blood, repeated transfusion and continuing continuously) (Khurana et al 2006).

The complications of illness and the level of depression had a significant relationship $(\mathrm{P}<0.05)$. The influence of disease complications on the degree of depression was significant. The greater the incidence of complications, the greater the possibility of mild depression. Complications of the disease in this study included growth disorders, liver disorders, heart failure, physical changes. These complications increase the stressor (frequency of transfusion, adverse effects of chelating agent, comorbidities, anxiety about the development of the disease), thereby increasing susceptibility to the appearance of depression. The existence of physical changes from splenomegaly, bone marrow expansion, short body, and various symptoms caused by the process of hemolysis. Physical differences compared to normal children wereimportant factors that influenced personality development and social function (Yengil et al 2014). Most of the studies had result of depression were mild depression. Thalassemia had a risk factor for causing mild depression by 2.3 times compared with moderate or severe depression. There was no theory that clearly explained the factors that affected a patient's ability to deal with depression, but there were several factors that influenced a patient's ability to deal with stress, including interpersonal and personal factors. Other studies suggested that the longer the duration of the disease, the more often patients were hospitalized regularly to get transfusions that led to higher risk of complications until depression appeared (Sharpe \& Rossiter 2002).

The degree of depression were influenced by the serum cortisol levels with significant relationship $(P<0.05)$. The greater the incidence of depression, the greater possibility of increasing serum cortisol levels. In this study, the increase in serum cortisol levels was influenced by the presence of chronic stress suffered by thalassemia patients. The disadvantage in this study was that there was no data on the value of other hormones produced by the anterior hypothalamus as a comparison of whether normal cortisol values were normal or a result of a condition of endocrine complications due to thalassemia. Some studies clarified that depression affected cortisol levels. In line with this, Balbo and Aisa study reinforced that HPA axis hyperactivity occured to associate with psychiatric disorders and clinical syndromes, such as depression and insomnia. This study supported the results of previous studies that depression hypercortisolism could arise due to adrenal cortex dysfunction in which the secretion of cortisol independently from ACTH that produced irregular cortisol secretion. Almost all types of physical or mental stress could cause increased secretion of ACTH and cortisol, cortisol increases by as much as 20 times. This effect was seen in the secretory response of adrenocortical after trauma (Balbo et al 2010).

\section{CONCLUSION}

Prevalence of mild depression in children with thalassemia major was $33.3 \%$. Complication of illness and serum cortisol level were significant as determinant factors of depression in Beta Major Thalassemia children.

\section{REFERENCES}

Aji DN, Silman C, Aryudi C, Centauri C, Andalia D, Astari D, Pitaloka D, Wawolumaya C, Sekartini R, Amalia P (2009). Faktor-faktor yang berhubungan dengan kualitas hidup pasien thalasemia mayor di pusat thalassemia dapartemen ilmu kesehatan anak RSCM. Sari Pediatri 11, 85-89.

Aydinok Y, Erermis S, Bukusoglu N, Yilmaz D, Solak U (2005). Psychosocial implications of thalassemia major. Pediatr Int 47, 84-89. 
Baldini M, Mancarella M, Cassinerio E, Marcon A, Ambrogio AG, Motta I (2017). Adrenal insufficiency: an emerging challenge in thalassemia? Am J Hematol 92, E119-E121.

Balbo M, Leproult R, Van Cauter E (2010). Impact of sleep and its disturbances on hypothalamo-pituitaryadrenal axis activity. International Journal of Endocrinology 2010.

Behdani F, Badiee Z, Hebrani P, Moharreri F, Badiee AH, Hajivosugh N, Rostami Z, Akhavanrezayat A (2015). Psychological aspects in children and adolescents with major thalassemia: a case-control study. Iran J Pediatr 25, e322.

Bulan S (2009). Faktor-faktor yang berhubungan dengan kualitas hidup anak Thalassemia beta mayor. Thesis, Program Pascasarjana Magister Ilmu Biomedik dan Program Pendidikan Dokter Spesialis Ilmu Kesehatan Anak, Semarang, Universitas Diponegoro.

Bush S, Mandel FS, Giardina PJ (1998). Future orientation and life expectations of adolescents and young adults with thalassemia major. Ann N Y Acad Sci 850, 361-369.

Ghanizadeh A, Khajavian S, Ashkani H (2006). Prevalence of psychiatric disorders, depression, and suicidal behavior in child and adolescent with thalassemia Major. J Pediatr Hematol Oncol 28, 781784.

Gladstone TRG, Beardslee WR (2009). The prevention of depression in children and adolescents: a review. Can J Psychiatry 54, 212-221.

Hastings CA, Torkildson JC, Agrawal AK (2012). Handbook of pediatric hematology and oncology: children's hospital \& research center Oakland 2nd ed, New Jersey, Wiley-Blackwell, p 36-43.

Olivieri NF, Weatherall DJ (2006). Thalassemias. In: Arceci RJ, Hann IM, Smith OP. Pediatric Hematology 3rd ed, Nwe Jersey, Blackwell Publishing, p 281-304.

Khurana A, Katyal S, Marwaha RK (2006). Psychosocial burden in thalassemia. Indian $\mathbf{J}$ Pediatr 73, 877-880.

Mariani D, Rustina Y, Nasution Y (2011). Analisis faktor yang memengaruhi kualitas hidup anak thalassemia beta mayor. Jurnal Keperawatan Indonesia 17.

Mazzone L, Battaglia L, Andreozzi F, Romeo MA, Mazzone D (2009). Emotional impact in betathalassemia major children following cognitivebehavioural family therapy and quality of life of ceregiving mothers. Clin Pract Epidemiol Ment Health 5 .

Mednick L, Yu S, Trachtenberg F, Xu Y, Kleinert DA, Giardina PJ, Kwiatkowski JL, Foote D, Thayalasuthan V, Porter JB, Thompson AA, Schilling L, Quinn CT, Neufeld EJ, Yamashita R (2010). Symptoms of depression and anxiety in patients with thalassemia: Prevalence and correlates in the thalassemia longitudinal cohort. AM J Hematol 85, 802-805.

Messina G, Colombo E, Cassinerio E, Ferri F, Curti R, Altamura C, Cappellini (2008). Psychosocial aspects and psychiatric disorders in young adult with thalassemia major. Intern Emerg Med 3, 339-343.

Nasiri M, Seyed HH, Shahmohammadi S (2014). Mental health status in patients with thalassemia major in Iran. J Pediatr Rev 2, 55-61.

Pattanashetti M, Mugali J, Pattanashetty N, Patil S (2017). A study of severity of depression in thalassemia patients. Int J Indian Psychol 4, 29-32.

Permono B, Ugrasena IDG (2006). Hemoglobin abnormal: thalasemia. In: Permono B, Sutaryo P, Ugrasena IDG, Windiastuti E, Abdulsalam M (eds). Buku ajar hematologi-onkologi anak, Jakarta, Badan Penerbit IDAI.

Sarker NR, Saha S, Shahriar A, Ghosh AK (2017). Recent advances in the management of thalassemia: a review update. Journal of Shaheed Suhrawardy Medical College 6, 31.

Sharpe D, Rossiter L (2002). Siblings of children with a chronic illness: a meta-analysis. J Pediatr Psychol 27, 699-710.

Sun S, Wang S (2014). The Children's depression inventory in worldwide child development research: a reliability generalization study. J Child Fam Stud 24, 2352-2363.

Velasco-Rodriguez D, Alonso-Dominguez J, GonzalezFenandez F, Villarrubia J, Ropero P, Martinez-Nieto J, de la Fuente F, Guillen R, Acedo N, Seri C, Cava F (2014). dß-Thalassemia trait: how can we discriminate it from $\beta$-thalassemia trait and iron deficiency anemia? Am J Clin Pathol 142, 567-573.

Venty V, Rismarini R, Puspitasari D, Kesuma Y, Indra RM (2018). Depression in children with thalassemia major: prevalence and contributing factors. Paediatrica Indonesiana 58, 263-268.

Yengil E, Acipayam C, Kokacya MH, Kurham F, Oktay G, Ozer C (2014). Anxiety, depression and quality of life in patients with beta thalassemia major and their caregivers. Int J Clin Exp Med 7, 2165-2172. 